\title{
A simple respirogram-based approach for the management of effluent from an activated sludge system
}

\section{Authors: Zhi-Hua Lia, , Yuan-Mo Zhua, Cheng-Jian Yanga, Tian-Yu Zhangb, Han-Qing Yu}

NOTICE: this is the author's version of a work that was accepted for publication in Bioresource Technology. Changes resulting from the publishing process, such as peer review, editing, corrections, structural formatting, and other quality control mechanisms may not be reflected in this document. Changes may have been made to this work since it was submitted for publication. A definitive version was subsequently published in Bioresource Technology, volume 261, August 2018 DOI\#10.1016/j.biortech.2018.03.134.

Li, Zhi-Hua, Yuan-Mo Zhu, Cheng-Jian Yang, Tian-Yu Zhang, and Han-Qing Yu. "A simple respirogram-based approach for the management of effluent from an activated sludge system." Bioresource Technology (August 2018). DOI:10.1016/j.biortech.2018.03.134. 


\title{
A simple respirogram-based approach for the management of effluent from an activated sludge system
}

\author{
Zhi-Hua Li ${ }^{\mathrm{a}, *}$, Yuan-Mo Zhu ${ }^{\mathrm{a}}$, Cheng-Jian Yang ${ }^{\mathrm{a}}$, Tian-Yu Zhang ${ }^{\mathrm{b}}$, Han-Qing $\mathrm{Yu}^{\mathrm{c}}$ \\ a School of Environmental and Municipal Engineering, Xi'an University of Architecture and Technology, Xi'an 710055, China \\ b Department of Mathematical Sciences, Montana State University, Bozeman, MT 59717-2400, USA \\ ${ }^{\mathrm{c}}$ CAS Key Laboratory of Urban Pollutant Conversion, Department of Chemistry, University of Science \& Technology of China, Hefei 230026, China
}

G R A P H I C A L A B S T R A C T

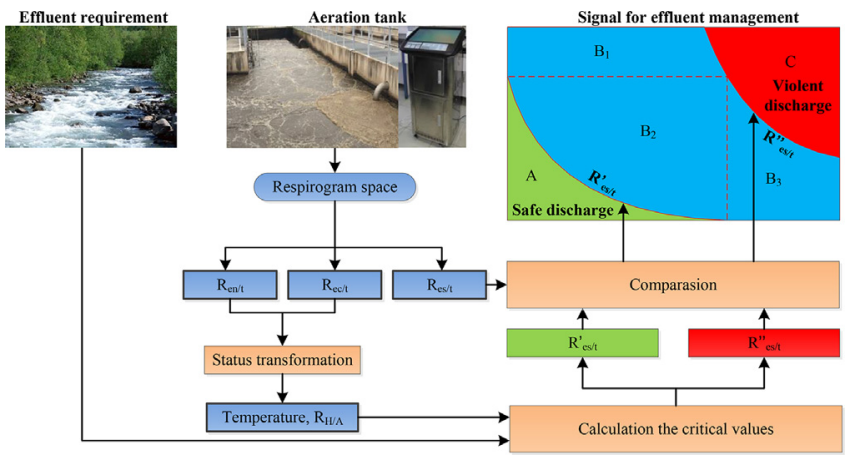

\begin{abstract}
A B S T R A C T
Managing wastewater treatment plant (WWTP) based on respirometric analysis is a new and promising field. In this study, a multi-dimensional respirogram space was constructed, and an important index $R_{\mathrm{es} / \mathrm{t}}$ (ratio of in-situ respiration rate to maximum respiration rate) was derived as an alarm signal for the effluent quality control. A smaller $R_{\text {es/t }}$ value suggests better effluent. The critical $R_{\text {es/t }}^{\prime}$ value used for determining whether the effluent meets the regulation depends on operational conditions, which were characterized by temperature and biomass ratio of heterotrophs to autotrophs. With given operational conditions, the critical $\mathrm{R}_{\mathrm{es} / \mathrm{t}}^{\prime}$ value can be calculated from the respirogram space and effluent conditions required by the discharge regulation, with no requirement for calibration of parameters or any additional measurements. Since it is simple, easy to use, and can be readily implemented online, this approach holds a great promise for applications.
\end{abstract}

\section{Introduction}

Adjustment of the operational conditions of a wastewater treatment plant (WWTP) is essential to its stable and optimal operation, and the feedback from effluent quality is the most frequently used strategy for in-time adjustment or optimization (Dalmau et al., 2015; Valverde-
Pérez et al., 2016). Thus, predicting effluent quality is critical to WWTP management, and many mathematical models have been proposed to predict WWTP effluent quality. Among these models, activated sludge models (ASMs) have been widely used, ranging from effluent quality prediction to operation condition evaluation and simulation of treatment processes, and they make WWTP operation more precise (Van 


\section{Nomenclature}

ASM activated sludge model

$\mathrm{b}_{\mathrm{A}} \quad$ autotrophic decay rate $\left[\mathrm{d}^{-1}\right], 0.12^{\#}$

$\mathrm{b}_{\mathrm{H}} \quad$ heterotrophic decay rate $\left[\mathrm{d}^{-1}\right], 0.62^{*}$

CAST cyclic activated sludge system

COD chemical oxygen demand

DO dissolved oxygen $\left[\mathrm{mg} \mathrm{L}^{-1}\right]$

$f_{p} \quad$ fraction of biomass leading to particulate products, $0.08^{*}$

$\mathrm{f}_{\mathrm{s}} \quad$ fraction of COD contributed to respiration [\%]

$\mathrm{K}_{\mathrm{NH}}$ ammonia half saturation coefficient for autotrophs growth $\left[\mathrm{mgN} \mathrm{L}^{-1}\right], 1.00^{*}$

$\mathrm{K}_{\mathrm{s}}$ half-saturation parameter for heterotrophic biomass [mgCOD L ${ }^{-1}$ ], 20*

MLSS Mixed liquid suspended solids $\left[\mathrm{mg} \mathrm{L}^{-1}\right]$

OUR oxygen uptake rate $\left[\mathrm{mgO}_{2}(\mathrm{~L} \mathrm{~min})^{-1}\right]$

$\mathrm{OUR}_{\mathrm{s}}$ in-situ respiration rate $\left[\mathrm{mgO}_{2}(\mathrm{~L} \mathrm{~min})^{-1}\right]$

OUR $_{\mathrm{q}}$ quasi-endogenous respiration rate $\left[\mathrm{mgO}_{2}(\mathrm{~L} \mathrm{~min})^{-1}\right]$

$\mathrm{OUR}_{\mathrm{e}}$ endogenous respiration rate $\left[\mathrm{mgO}_{2}(\mathrm{~L} \mathrm{~min})^{-1}\right]$

$\mathrm{OUR}_{\mathrm{n}}$ nitrogen stimulated respiration rate $\left[\mathrm{mgO}_{2}(\mathrm{~L} \mathrm{~min})^{-1}\right]$

$\mathrm{OUR}_{\mathrm{c}}$ carbon source stimulated respiration rate $\left[\mathrm{mgO}_{2}\right.$ $(\mathrm{L} \mathrm{min})^{-1}$ ]

OUR $_{\mathrm{t}} \quad$ maximum respiration rate $\left[\mathrm{mgO}_{2}(\mathrm{~L} \mathrm{~min})^{-1}\right]$

PAOs phosphate-accumulating organisms

PLC programmable logic controller
$\mathrm{R}_{\mathrm{es} / \mathrm{t}} \quad$ relative to $\frac{O U R_{S}}{O U R_{t}}$

$R_{\text {es/t }}^{\prime}$ the corresponding $R_{e s / t}$ for safe boundary line

$\mathrm{R}^{\prime \prime}{ }_{\mathrm{es} / \mathrm{t}}$ the corresponding $\mathrm{R}_{\mathrm{es} / \mathrm{t}}$ for violent boundary line

$\mathrm{R}_{\mathrm{en} / \mathrm{t}}$ relative to $\frac{O U R_{e}+O U R_{n}}{O U R_{t}}$

$\mathrm{R}_{\mathrm{ec} / \mathrm{t}} \quad$ relative to $\frac{O U R_{e}+O U R_{c}}{O U R_{t}}$

$\mathrm{R}_{\mathrm{H} / \mathrm{A}} \quad$ relative to $\frac{X_{H}}{X_{A}}$

SCADA supervisory control and data acquisition

$\mathrm{S}_{\mathrm{i}, \mathrm{j}} \quad$ normalized sensitivity coefficient

SS readily biodegradable substrate $\left[\mathrm{mgCOD} \mathrm{L}^{-1}\right.$ ]

TN total nitrogen

TP total phosphorus

WWTP wastewater treatment plant

$\mathrm{X}_{\mathrm{S}} \quad$ slowly biodegradable substrate $\left[\mathrm{mgCOD} \mathrm{L}^{-1}\right]$

$\mathrm{Y}_{\mathrm{A}} \quad$ autotrophic yield coefficient $\left[\mathrm{mg}\right.$ cell COD $\left.(\mathrm{mgCOD})^{-1}\right]$, $0.24^{*}$

$\mathrm{Y}_{\mathrm{H}} \quad$ heterotrophic yield coefficient [mg cell COD $(\mathrm{mgCOD})^{-1}$ ], $0.67^{*}$

$\mu_{\mathrm{A}} \quad$ maximum specific autotrophic growth rate $\left[\mathrm{d}^{-1}\right], 0.8^{*}$

$\mu_{H} \quad$ maximum specific heterotrophic growth rate $\left[d^{-1}\right], 6.00^{*}$

* these defaults which were used in the simplified version of ASM1 from Melcer (2004) $\left(\mathrm{T}=20^{\circ} \mathrm{C}\right)$.

\# this default which were used in the simplified version of ASM1 from Henze et al. (2000) $\left(\mathrm{T}=20^{\circ} \mathrm{C}\right)$
Loosdrecht et al., 2015; Bahar and Ciggin, 2016). However, operating WWTP using ASMs is hard because of the complex and diverse nature of ASM components. Most of the parameters and kinetic coefficients in ASMs vary from case to case, the pre-application procedures, such as parameter calibration, sensitivity analysis and wastewater component estimation, are time-consuming and labor-intensive. These factors also introduce barriers against the wide applications of ASMs for full-scale wastewater treatment management. According to an international survey, approximately $35 \%$ of users still believe that the models do not solve their problems or achieve their goals (Hauduc et al., 2009).

The biological characteristics of sludge are the key factors governing effluent quality. Statistical models, e.g., neural networks and multivariant regressions, are also used to establish the relationships between the effluent quality and the operational factors (Dürrenmatt and Gujer, 2012; Hreiz et al., 2015; Foscoliano et al., 2016). These models combine water quality prediction and operation optimization and have been successfully applied in real-time monitoring of WWTPs. However, statistical models require a considerable amount of previously accumulated data for training and are usually trained on a case by case basis, thus cannot be easily applied to general cases. Consequently, these models cannot predicate conditions that, historically, rarely or never occurred (Dürrenmatt and Gujer, 2012; Xu et al., 2017).

Neither the biological mechanical models such as ASMs, nor the statistical models such as neural networks, can be easily used by operators in full-scale WWTPs. As a result, despite of great achievements in these models (Van Loosdrecht et al., 2015), operators still run the plants according to their prior experiential rules, at least in most plants in developing countries like China.

Respirograms have been widely applied for evaluating kinetic and stoichiometric characteristics of activated sludge (Ciggin and Orhon, 2014; Kor-Bicakci et al., 2015; Capodici et al., 2016; Mannina et al., 2016a). As one of the important indexes, oxygen uptake rate (OUR) is frequently used for describing the properties of activated sludge. OUR itself only provides limited information. For example, endogenous and exogenous respiration values could be used to identify an available substrate source (Jubany et al., 2009; Zamouche-Zerdazi et al., 2014), absence or presence of calcium-induced respiration could be used to evaluate the robustness of activated sludge (Li et al., 2018a) and the endogenous respiration itself also provides useful information (Friedrich and Takács, 2013). However, the combined usage of several OURs measured under different conditions as an entire set exhibits a great capability of elucidating the biological mechanisms behind observations. For instance, the ratio of endogenous and maximum respiration could well indicate the physiological status of activated sludge (Friedrich et al., 2015), and the recovery potential after shocking loading (Li et al., 2018b).

To further take advantage of such a combination, the new concept of multi-dimensional respirogram space was proposed in this work, aiming to provide an efficient management tool for WWTP operators for quick and easy determination of whether the effluent is qualified according to the local discharge regulations without complex parameter measurements.

\section{Materials and methods}

\subsection{Conceptual rationale of the method}

In summary, Sections 2.2 and 2.3 give the source of samples and experimental procedures for determining various respiration rates. Section 2.4 points out what information extracted from the respirogram space could be used to evaluate the effluent quality. Section 2.5 explains how to calculate the respirogram and transform the respirogram status to operational status using ASM1 model and proposes a respirogram-based method that can quickly and easily determine whether the effluent is qualified.

\subsection{Source of the samples}

Activated sludge and raw wastewater samples were taken from seven full-scale WWTPs in two provinces of northwestern China. The detailed information about these WWTPs is listed in Table 1.

\subsection{Determination of the respirogram space}

Respirogram space, composed of a series of OURs, was introduced in this work. The respiration rates were measured offline using automatic 
respirogram equipment (WBM400, Xi'an Lvbiao Water Environmental Technology Co., China) consisting of a dissolved oxygen (DO) probe (VisiFerm DO 120, Hamilton Co., Switzerland), a pH probe (Polilyte Plus H Arc 120, Hamilton Co., Switzerland) and a programmable logic controller (PLC). The following procedures were adopted for the measurement:

a) A total of $0.3 \mathrm{~L}$ of activated sludge and $0.9 \mathrm{~L}$ of tap water were pumped into a built-in Plexiglas sleeve vessel in the equipment with a water bath, resulting in a 0.25 -fold raw sludge concentration. Online monitoring of the $\mathrm{pH}$ variation of the built-in vessel in the equipment maintained the measuring cell at a $\mathrm{pH}$ of 7.5-8.5 by adding $0.1 \mathrm{~mol} \mathrm{~L}^{-1} \mathrm{HCl}$ or $\mathrm{NaOH}$ solution. And the equipment was operated at a constant temperature of $20 \pm 0.5^{\circ} \mathrm{C}$. Aeration was provided until DO concentration reached $7 \mathrm{mg} \mathrm{L}^{-1}$ and then was stopped while mixing was conducted.

b) An in-situ OUR, denoted as $\mathrm{OUR}_{\mathrm{s}}$, was measured with the decline of DO concentration during the mixing without aeration phase.

c) The measuring cell was then washed three times using phosphate buffer saline solution, and a quasi-endogenous respiration rate, denoted as $\mathrm{OUR}_{\mathrm{q}}$, was obtained using the same procedure.

d) Endogenous OUR, denoted as $\mathrm{OUR}_{\mathrm{e}}$, was measured after the measuring cell was aerated for $2 \mathrm{~h}$.

e) Ammonium chloride (TIANLI, Tianjin, China) was then pumped into the measuring cell, resulting in a $50 \mathrm{mg} \mathrm{NH}_{4}{ }^{+}-\mathrm{N} \mathrm{L}^{-1}$ in the bulking solutions, and the OUR was measured (denoted as OUR $_{\text {en }}$ ).

f) The OUR en consisted of the endogenous $\mathrm{OUR}_{e}$ and the nitrogenstimulated OUR ; and

g) Finally, a certain amount of sodium acetate (TIANLI, Tianjin, China) was pumped into the measuring cell to reach a final concentration of $300 \mathrm{mg} \mathrm{L}^{-1}$ in the bulking solutions in terms of COD; this OUR was denoted as $\mathrm{OUR}_{\mathrm{t}}$, which could be considered as a summary of OUR $\mathrm{e}_{\mathrm{e}}$, $\mathrm{OUR}_{\mathrm{n}}$ and $\mathrm{OUR}_{\mathrm{c}}$ (the carbon source-stimulated OUR).

The offline determination procedure of the respirogram space is detailed in Fig. 1.

\subsection{Use of respirogram space for effluent quality control}

The above determination procedure indicates that the following factors affecting the effluent quality were taken into account in the respirogram space

(i) the activities of sludge for COD and ammonia removal capacities, described by OUR $\mathrm{C}_{\mathrm{c}}$ and $\mathrm{OUR}_{\mathrm{n}}$, respectively

(ii) the residual COD and $\mathrm{NH}_{4}{ }^{+}-\mathrm{N}$ in the effluent that contributed to the $\mathrm{OUR}_{\mathrm{s}}$

and (iii) the operational conditions, such as temperature that affected the kinetic properties of activated sludge and the composition of heterotrophs and autotrophs, which would determine either COD or $\mathrm{NH}_{4}{ }^{+}$-N would be the controlling factor. The information extracted from respirogram space could be used to evaluate the effluent quality.



Fig. 1. Procedures for the offline determination of respirogram rate.

\subsection{Calculation of the respirogram and transformation from the} respirogram status to the operational status

For practical use, several indexes were derived from the respirogram space. The ratio of the in-situ respiration rate to the maximum respiration rate, denoted as $R_{\mathrm{es} / \mathrm{t}}$, was introduced for describing the nature of the effluent. The ratio of the sum of the endogenous respiration rate and the nitrogen-stimulated respiration rate to the maximum respiration rate $\left(R_{e n / t}\right)$ and the ratio of the sum of the endogenous respiration rate and the carbon-stimulated respiration rate to the maximum respiration rate $\left(R_{e c / t}\right)$ were introduced for describing of the nature of the activated sludge. The measured value of $R_{\mathrm{es} / \mathrm{t}}$ was then compared to the critical values of $R_{\mathrm{es} / \mathrm{t}}$, which is a function of effluent

Table 1

Information of WWTPs investigated.

\begin{tabular}{|c|c|c|c|c|c|c|c|}
\hline WWTP & Type of sewage & Operation model & Aeration tank volume $\left(\mathrm{m}^{3}\right)$ & Aeration tank HRT (h) & SRT (d) & Flow $\left(\times 10^{4} \mathrm{~m}^{3} \mathrm{~d}^{-1}\right)$ & $\operatorname{MLSS}\left(\mathrm{mg} \mathrm{L}^{-1}\right)$ \\
\hline 1 & Domestic sewage & Oxidation ditch & 4900 & 24 & $17-18$ & 1.0 & $2000-4000$ \\
\hline 2 & Municipal wastewater & Orbal oxidation ditch & 18400 & 19 & $19-21$ & 15.0 & $6000-7000$ \\
\hline 3 & Municipal wastewater & DE oxidation ditch & 26000 & 10 & 14 & 10.0 & $7000-8000$ \\
\hline 4 & Domestic sewage & Anaerobic-Anoxic-Oxic & 6300 & 10 & 7 & 2.5 & $3500-4600$ \\
\hline 5 & Municipal wastewater & Anaerobic-Anoxic-Oxic & 18800 & 9 & 16 & 20.0 & $3000-5500$ \\
\hline 6 & Municipal wastewater & Anoxic- Anaerobic-Oxic & 22700 & 8 & 14 & 50.0 & $4000-5000$ \\
\hline 7 & Domestic sewage & CAST & 3200 & 12 & $23-25$ & 1.4 & $3000-3800$ \\
\hline
\end{tabular}


quality required by regulation, to determine whether the effluent was safe to discharge (Fig. 2). Obviously, the method is meaningful only when the measured and critical values of $\mathrm{R}_{\mathrm{es} / \mathrm{t}}$ were obtained for active sludge of the same nature and under same operational conditions. The following mathematical calculations were carried out for obtaining these appropriate critical values.

The coordinates of the respirogram space could be calculated using the following equations based on a simplified model derived from ASM1 with some modification (Henze et al., 2000), and the meanings of all symbols could be found in the Nomenclature:

$$
\begin{aligned}
& O U R_{s}=O U R_{\mathrm{e}}+\frac{1-Y_{H}}{Y_{H}} \mu_{H} \frac{S_{s}}{K_{s}+S_{s}} X_{H}+\frac{4.57-Y_{A}}{Y_{A}} \mu_{A} \frac{S_{N H}}{K_{N H}+S_{N H}} X_{A} \\
& O U R_{n}=\frac{4.57-Y_{A}}{Y_{A}} \mu_{A} X_{A} \\
& O U R_{c}=\frac{1-Y_{H}}{Y_{H}} \mu_{H} X_{H} \\
& O U R_{\mathrm{t}}=O U R_{\mathrm{e}}+\frac{1-Y_{H}}{Y_{H}} \mu_{H} X_{H}+\frac{4.57-Y_{A}}{Y_{A}} \mu_{A} X_{A}
\end{aligned}
$$

Since the ASM1 model is based on the death-regeneration concept, no oxygen is needed for the endogenous respiration. Although it could well predict the effluent quality of activated sludge systems (Van Loosdrecht and Henze, 1999), the assumption of no oxygen for endogenous respiration is not true for the measured OUR profiles. To account for this, a simple endogenous respiration process was introduced to describe the endogenous respiration rate $\mathrm{OUR}_{\mathrm{e}}$.

$O U R_{e}=\left(1-f_{p}\right)\left(b_{H} X_{H}+b_{A} X_{A}\right)$

Therefore, the $\mathrm{R}_{\mathrm{es} / \mathrm{t}}, \mathrm{R}_{\mathrm{en} / \mathrm{t}}$, and $\mathrm{R}_{\mathrm{ec} / \mathrm{t}}$ could be calculated using Eqs. (6)-(8), respectively.

$$
\begin{aligned}
R_{e s / t}= & \frac{\left(1-f_{p}\right)\left(b_{H} \frac{X_{H}}{X_{A}}+b_{A}\right)+\frac{1-Y_{H}}{Y_{H}} \mu_{H} \frac{S_{s}}{K_{S}+S_{s}} \frac{X_{H}}{X_{A}}+\frac{4.57-Y_{A}}{Y_{A}} \mu_{A} \frac{S_{N H}}{K_{N H}+S_{N H}}}{\left(1-f_{p}\right)\left(b_{H} \frac{X_{H}}{X_{A}}+b_{A}\right)+\frac{1-Y_{H}}{Y_{H}} \mu_{H} \frac{X_{H}}{X_{A}}+\frac{4.57-Y_{A}}{Y_{A}} \mu_{A}} \\
= & \frac{\left(1-f_{p}\right)\left(b_{H} R_{H / A}+b_{A}\right)+\frac{1-Y_{H}}{Y_{H}} \mu_{H} \frac{S_{S}}{K_{S}+S_{s}} R_{H / A}+\frac{4.57-Y_{A}}{Y_{A}} \mu_{A} \frac{S_{N H}}{K_{N H}+S_{N H}}}{\left(1-f_{p}\right)\left(b_{H} R_{H / A}+b_{A}\right)+\frac{1-Y_{H}}{Y_{H}} \mu_{H} R_{H / A}+\frac{4.57-Y_{A}}{Y_{A}} \mu_{A}}
\end{aligned}
$$

$$
\begin{aligned}
R_{\mathrm{en} / t}= & \frac{\left(1-f_{p}\right)\left(b_{H} \frac{X_{H}}{X_{A}}+b_{A}\right)+\frac{4.57-Y_{A}}{Y_{A}} \mu_{A}}{\left(1-f_{p}\right)\left(b_{H} \frac{X_{H}}{X_{A}}+b_{A}\right)+\frac{1-Y_{H}}{Y_{H}} \mu_{H} \frac{X_{H}}{X_{A}}+\frac{4.57-Y_{A}}{Y_{A}} \mu_{A}} \\
= & \frac{\left(1-f_{p}\right)\left(b_{H} R_{H / A}+b_{A}\right)+\frac{4.57-Y_{A}}{Y_{A}} \mu_{A}}{\left(1-f_{p}\right)\left(b_{H} R_{H / A}+b_{A}\right)+\frac{1-Y_{H}}{Y_{H}} \mu_{H} R_{H / A}+\frac{4.57-Y_{A}}{Y_{A}} \mu_{A}}
\end{aligned}
$$

$$
\begin{aligned}
R_{\mathrm{ec} / t}= & \frac{\left(1-f_{p}\right)\left(b_{H} \frac{X_{H}}{X_{A}}+b_{A}\right)+\frac{1-Y_{H}}{Y_{H}} \mu_{H} \frac{X_{H}}{X_{A}}}{\left(1-f_{p}\right)\left(b_{H} \frac{X_{H}}{X_{A}}+b_{A}\right)+\frac{1-Y_{H}}{Y_{H}} \mu_{H} \frac{X_{H}}{X_{A}}+\frac{4.57-Y_{A}}{Y_{A}} \mu_{A}} \\
= & \frac{\left(1-f_{p}\right)\left(b_{H} R_{H / A}+b_{A}\right)+\frac{1-Y_{H}}{Y_{H}} \mu_{H} R_{H / A}}{\left(1-f_{p}\right)\left(b_{H} R_{H / A}+b_{A}\right)+\frac{1-Y_{H}}{Y_{H}} \mu_{H} R_{H / A}+\frac{4.57-Y_{A}}{Y_{A}} \mu_{A}}
\end{aligned}
$$

The effluent predication (e.g., ASM1) was most sensitive to parameters associated with the growth and decay of heterotrophs and autotrophs, i.e., $Y_{H}, \mu_{H}, K_{s}, b_{H}, \mu_{A}, K_{N H}$, and $b_{A}$ (Petersen et al., 2002). Thus, a sensitivity analysis of these parameters in Eqs. (6)-(8) on $R_{\mathrm{es} / \mathrm{t}}$ calculation was performed to determine whether calibration of these parameter was necessary. The normalized sensitivity coefficient $S_{i, j}$ is defined as Eq. (9):

$S_{i . j}=\left|\frac{\Delta R_{e s / t(i)} / R_{e s / t(i)}}{\Delta p_{j} / p_{j}}\right|$

A $10 \%$ increase in the parameters $\left(\mathrm{p}_{\mathrm{j}}\right)$ at $20^{\circ} \mathrm{C}$ on the output of $\mathrm{R}_{\mathrm{es} / \mathrm{t}}$ was calculated for the estimation of $S_{i, j}$, and sensitivity analysis of each parameter was performed separately with the measured values of $R_{\mathrm{ec} / \mathrm{t}}$ and $R_{e n / t}$ as input variables for each plants. If $S_{i, j}<0.25$, the parameter $p_{j}$ is considered to have no significant impact on $R_{e s / t}$ output (Petersen et al., 2002). In this case, the calibration of these parameters was not necessary.

In Eqs. (6)-(8), $\mu_{A}, \mu_{H}, b_{A}$ and $b_{H}$ depend on temperature, which could be described using the Arrhenius equation. Thus, $\mathrm{R}_{\mathrm{es} / \mathrm{t}}$ depends on the effluent, temperature ( $\mathrm{T}$ ) and biomass ratio of heterotrophs and autotrophs $\left(R_{H / A}\right)$. However, $R_{e n / t}$ and $R_{e c / t}$ depend on $T$ and $R_{H / A}$ only. In the proposed method of this study, the operational conditions ( $\mathrm{T}$ and $\mathrm{R}_{\mathrm{H} / \mathrm{A}}$ ) were calculated using Eqs. (7) and (8) with the measured values of $R_{\mathrm{en} / \mathrm{t}}$ and $R_{\mathrm{ec} / \mathrm{t}}$, then the resulting values along with required effluent conditions (COD and ammonia concentration of effluent) were used in Eq. (6) to determine the corresponding critical $R_{e s / t}$. Namely, the critical $R_{e s / t}$ is a function of $R_{e n / t}, R_{e c / t}$, and the required effluent conditions. More precisely, given parameter values of $\mu_{A}, \mu_{H}, b_{A}$ and $b_{H}$ at 20 and $10^{\circ} \mathrm{C}$, their values at some discrete intermediate temperatures were calculated using Arrhenius equation, and then $R_{e n / t}$ and $R_{e c / t}$ were calculated at discrete temperature and biomass ratio values within reasonable range using Eqs. (7) and (8), and the values were saved in a table. After that, for given $R_{e n / t}$ and $R_{e c / t}$ (the measured values), the corresponding $\mathrm{T}$ and $\mathrm{R}_{\mathrm{H} / \mathrm{A}}$ can be obtained using interpolation with the table obtained above. Finally, the critical $\mathrm{R}_{\mathrm{es} / \mathrm{t}}$ can be calculated using Eq. (6) with the following effluent requirements.

With the discharge standard of pollutants for municipal wastewater treatment plant (GB 18918-2002) in China as an example, the A-level discharge limitation is as follows

(i) $\mathrm{COD}<50 \mathrm{mg} \mathrm{L}^{-1}$ and (ii) $\mathrm{NH}_{4}{ }^{+}-\mathrm{N}<5 \mathrm{mg} \mathrm{L}^{-1}$ or $8 \mathrm{mg} \mathrm{L}^{-1}$ (when the temperature is less than $12^{\circ} \mathrm{C}$ ).

It should be noted that only partial constituents of effluent account

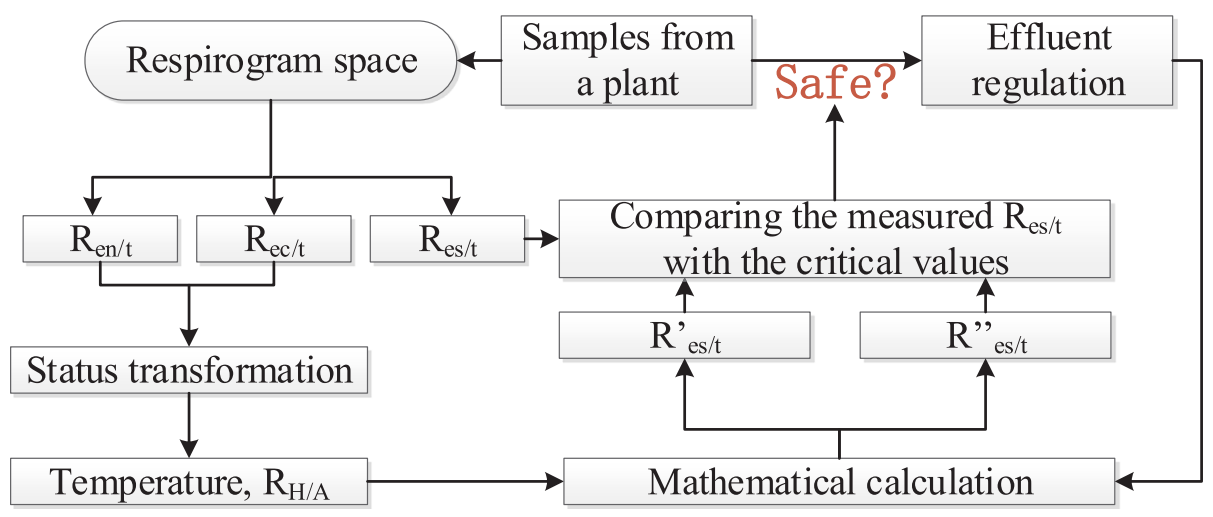

Fig. 2. Procedures for effluent management using multi-dimensional respirogram space. 
for the respiration rate, and the fraction of these constituents should be estimated beforehand. However, the fraction of particulate constituents of effluent depends on the hydraulic conditions and the performance of the settling tanks, which is beyond the biological process itself. Also, since the total time needed for determining the respirogram space was approximately $5 \mathrm{~h}$ and $\mathrm{X}_{\mathrm{S}}$ was slowly degraded in the entire process, $\mathrm{X}_{\mathrm{S}}$ contributed almost equally to each coordinate of the respirogram space by a very small amount, and its effect could be neglected in the calculation. Thus, only soluble COD fraction (i.e., Ss) was considered in this study. The fraction of Ss in total COD, denoted as $\mathrm{f}_{\mathrm{s}}$, has been reported in the range of $23 \%$ to $80 \%$ for domestic wastewater (Namour and Müller, 1998; Dulekgurgen et al., 2006; Karahan et al., 2008). A much smaller fraction $\left(f_{s}=10 \%\right)$ was selected in our method for the qualified COD effluent, resulting in more strict control of OURs because of less Ss, which makes a more conservative estimate of the alarm signal and provides a safer operation standard. The following conditions were assumed for the $\mathrm{R}_{\text {es/t }}$ estimation

(i) Ss and $\mathrm{NH}_{4}{ }^{+}-\mathrm{N}$ were $5\left(50 \times \mathrm{f}_{\mathrm{s}}\right)$ and $0 \mathrm{mg} / \mathrm{L}$, respectively, and (ii) $\mathrm{Ss}$ and $\mathrm{NH}_{4}{ }^{+}-\mathrm{N}$ were 0 and $5 \mathrm{mg} / \mathrm{L}$, respectively, two $\mathrm{R}_{\mathrm{es} / \mathrm{t}}$ values could be obtained, and the smaller one was assigned as the critical $\mathrm{R}_{\text {es/ }}^{\prime}$ t. If the measured $R_{e s / t}$ was less than $R_{\text {es/t }}^{\prime}$, the effluent was qualified. The critical $R^{\prime \prime}$ es/t, above which violent discharge conditions occurred, was obtained at given Ss and $\mathrm{NH}_{4}{ }^{+}-\mathrm{N}$ of $5\left(50 \times \mathrm{f}_{\mathrm{s}}\right)$ and $5 \mathrm{mg} / \mathrm{L}$, respectively.

\section{Results and discussion}

\section{1. $R_{e s / t}$ as a primary index for describing activated sludge system performance}

The characteristics of the influent, effluent and respirogram space from different WWTPs are summarized in Table 2. The COD and $\mathrm{NH}_{4}{ }^{+}$$\mathrm{N}$ levels of the effluents from Plants 2 and 4 exceeded the upper limits of the Chinese Discharge Standards, while the effluent COD of Plant 3 was unqualified, but its effluent $\mathrm{NH}_{4}{ }^{+}-\mathrm{N}$ was qualified. The effluents of all other plants met the Standards. On the one hand, the value of $\mathrm{OUR}_{s}$ was highly related to the residual COD and $\mathrm{NH}_{4}{ }^{+}$-N levels of the effluent, with a higher OUR $\mathrm{S}_{\mathrm{s}}$ value indicating more COD and $\mathrm{NH}_{4}{ }^{+}-\mathrm{N}$ in the effluent. On the other hand, OUR $\mathrm{t}_{\mathrm{t}}$ was positively correlated to the maximum respiration capacity of the activated sludge. Therefore, the value of $\mathrm{R}_{\mathrm{es} / \mathrm{t}}$ could be used to describe the residual COD and $\mathrm{NH}_{4}{ }^{+}-\mathrm{N}$ levels of the effluent, which were available for possible further degradation. Namely, a smaller $R_{\mathrm{es} / \mathrm{t}}$ value means a better treatment performance of activated sludge systems, as evidenced by the data from Plants 2-4, where the plants with unqualified effluents had higher values of $R_{\text {es/t }}$.

\subsection{Calculation of operational status from respirogram space}

The effects of temperature and $\mathrm{R}_{\mathrm{H} / \mathrm{A}}$ on the respirogram space were calculated with Eqs. (7) and (8). Thus, the respirogram space point $\left(R_{e c}\right.$ / $\left.t, R_{e n / t}\right)$ appropriately indicates the operational status $\left(T, R_{H / A}\right)$. For a given respirogram status point that can be easily measured either online or offline, the corresponding temperature and biomass ratio could be determined (Fig. 3). Consequently, safe and violent area boundary lines that were governed by biomass ratio and temperature could also be determined using the respirogram itself. For a given biomass ratio (Fig. 3), an increase in temperature (e.g., from status points A to B) resulted in a higher $R_{\mathrm{en} / \mathrm{t}}$ and a lower $\mathrm{R}_{\mathrm{ec} / \mathrm{t}}$, suggesting that nitrification was more active at a higher temperature than heterotrophic growth. Consequently, COD might be the limiting factor for controlling the effluent quality, and a higher $\mathrm{R}_{\mathrm{es} / \mathrm{t}}$ should be controlled. However, for a given temperature, an increase in the biomass ratio (e.g., from points A to $\mathrm{C}$ ) that might be caused by unfavorable conditions for nitrifiers resulted in a smaller $\mathrm{R}_{\mathrm{en} / \mathrm{t}}$ and larger $\mathrm{R}_{\mathrm{ec} / \mathrm{t}}$. Consequently, $\mathrm{NH}_{4}{ }^{+}-\mathrm{N}$ concentration became a controlling factor for the effluent quality, which would require a smaller $R_{\mathrm{es} / \mathrm{t}}$.

\subsection{Sensitivity analysis for the calculation of critical values of $R^{\prime}{ }_{e s / t}$ and $R^{\prime \prime}{ }_{e s / t}$}

The normalized sensitivity coefficient $S_{i, j}$ describing the sensitivity of kinetic and stoichiometric parameters in Eqs. (6)-(8) on $R_{\text {es/t }}$ estimation, was calculated using Eq. (9), and results are given in Table 3. The most influential parameter for all plants was the ammonia affinity coefficient $K_{N H}$ with $S_{i, j}$ value of $0.1578-0.1599(<0.25)$, and the other $S_{i, j}$ values of all plants were much less than 0.25 . This result suggests that calibration of these parameters is unnecessary. Thus, the default values could be used to estimate $R_{\mathrm{es} / \mathrm{t}}$ (Henze et al., 2000).

\subsection{Evaluation of WWTP effluent status with respirogram space}

Temperature $\mathrm{T}$ and biomass ratio $\mathrm{R}_{\mathrm{H} / \mathrm{A}}$ vary from one plant to another and can be calculated from the respirogram space as discussed above. Taking Plant 1 as an example, the $R_{\mathrm{en} / \mathrm{t}}$ and $R_{\mathrm{ec} / \mathrm{t}}$ values were measured as 0.32 and 0.78 on average, respectively, and from Eqs. (7)

Table 2

Overall performance and respirogram of WWTPs.

\begin{tabular}{|c|c|c|c|c|c|c|c|c|}
\hline WWTPs & & $\begin{array}{l}1 \\
(n=3)\end{array}$ & $\begin{array}{l}2 \\
(n=3)\end{array}$ & $\begin{array}{l}3 \\
(n=2)\end{array}$ & $\begin{array}{l}4 \\
(n=3)\end{array}$ & $\begin{array}{l}5 \\
(n=2)\end{array}$ & $\begin{array}{l}6 \\
(n=2)\end{array}$ & $\begin{array}{l}7 \\
(n=4)\end{array}$ \\
\hline \multirow[t]{2}{*}{ Influent } & $\operatorname{COD}\left(\mathrm{mg} \mathrm{L}^{-1}\right)$ & $670 \pm 127$ & $164 \pm 77$ & $309 \pm 35$ & $583 \pm 21$ & $310 \pm 11$ & $239 \pm 8$ & $128 \pm 11$ \\
\hline & $\mathrm{NH}_{4}^{+}-\mathrm{N}\left(\mathrm{mg} \mathrm{L}^{-1}\right)$ & $69 \pm 21$ & $34 \pm 4$ & $30 \pm 12$ & $73 \pm 6$ & $34 \pm 1$ & $25 \pm 4$ & $26 \pm 3$ \\
\hline \multirow[t]{2}{*}{ Effluent } & $\operatorname{COD}\left(\mathrm{mg} \mathrm{L}^{-1}\right)$ & $43 \pm 12$ & $59 \pm 5$ & $61 \pm 2$ & $62 \pm 4$ & $43 \pm 2$ & $41 \pm 3$ & $31 \pm 2$ \\
\hline & $\mathrm{NH}_{4}^{+}-\mathrm{N}\left(\mathrm{mg} \mathrm{L}^{-1}\right)$ & $3.9 \pm 0.4$ & $6.2 \pm 0.6$ & $4.2 \pm 0.1$ & $6.1 \pm 0.1$ & $4.5 \pm 0.2$ & $4.0 \pm 0.2$ & $2.3 \pm 1.0$ \\
\hline Respirogram & $0.25 \mathrm{OUR}_{\mathrm{s}}\left(\mathrm{mg} \mathrm{L}^{-1} \mathrm{~h}^{-1}\right)$ & $3.9 \pm 0.5$ & $19.4 \pm 2.8$ & $4.6 \pm 0.9$ & $11.3 \pm 0.8$ & $3.1 \pm 0.4$ & $4.5 \pm 0.5$ & $2.6 \pm 0.3$ \\
\hline \multirow[t]{8}{*}{ Space* } & $0.25 \operatorname{OUR}_{\mathrm{q}}\left(\mathrm{mg} \mathrm{L}^{-1} \mathrm{~h}^{-1}\right)$ & $2.7 \pm 0.6$ & $3.6 \pm 0.5$ & $1.9 \pm 0.2$ & $3.0 \pm 0.3$ & $2.6 \pm 0.2$ & $3.4 \pm 0.7$ & $2.2 \pm 0.2$ \\
\hline & $0.25 \mathrm{OUR}_{\mathrm{e}}\left(\mathrm{mg} \mathrm{L}^{-1} \mathrm{~h}^{-1}\right)$ & $2.5 \pm 0.5$ & $3.4 \pm 0.1$ & $2.1 \pm 0.2$ & $3.0 \pm 0.0$ & $2.3 \pm 0.7$ & $2.7 \pm 0.2$ & $2.3 \pm 0.2$ \\
\hline & $0.25 \mathrm{OUR}_{\mathrm{n}}\left(\mathrm{mg} \mathrm{L}^{-1} \mathrm{~h}^{-1}\right)$ & $5.5 \pm 0.9$ & $6.5 \pm 2.1$ & $3.7 \pm 0.0$ & $5.5 \pm 1.2$ & $5.2 \pm 0.7$ & $5.0 \pm 0.5$ & $3.1 \pm 0.7$ \\
\hline & $0.25 \mathrm{OUR}_{\mathrm{c}}\left(\mathrm{mg} \mathrm{L}^{-1} \mathrm{~h}^{-1}\right)$ & $16.9 \pm 3.3$ & $23.2 \pm 4.3$ & $11.5 \pm 0.8$ & $17.8 \pm 1.7$ & $16.0 \pm 2.0$ & $17.7 \pm 1.1$ & $15.2 \pm 2.7$ \\
\hline & $0.25 \mathrm{OUR}_{\mathrm{t}}\left(\mathrm{mg} \mathrm{L}^{-1} \mathrm{~h}^{-1}\right)$ & $24.9 \pm 4.5$ & $33.1 \pm 6.6$ & $17.2 \pm 1.0$ & $26.2 \pm 2.9$ & $24.0 \pm 2.5$ & $25.4 \pm 1.4$ & $20.7 \pm 3.5$ \\
\hline & $\mathrm{R}_{\mathrm{en} / \mathrm{t}}$ & $0.32 \pm 0.01$ & $0.30 \pm 0.02$ & $0.34 \pm 0.00$ & $0.32 \pm 0.01$ & $0.34 \pm 0.02$ & $0.31 \pm 0.01$ & $0.27 \pm 0.02$ \\
\hline & $\mathrm{R}_{\mathrm{ec} / \mathrm{t}}$ & $0.78 \pm 0.01$ & $0.81 \pm 0.03$ & $0.78 \pm 0.01$ & $0.79 \pm 0.02$ & $0.78 \pm 0.00$ & $0.80 \pm 0.01$ & $0.85 \pm 0.02$ \\
\hline & $\mathrm{R}_{\mathrm{es} / \mathrm{t}}$ & $0.16 \pm 0.01$ & $0.60 \pm 0.06$ & $0.26 \pm 0.03$ & $0.44 \pm 0.08$ & $0.13 \pm 0.03$ & $0.17 \pm 0.01$ & $0.13 \pm 0.02$ \\
\hline \multirow[t]{4}{*}{ Verification } & $\mathrm{R}_{\mathrm{es} / \mathrm{t}}^{\prime}$ & 0.236 & 0.250 & 0.252 & 0.246 & 0.252 & 0.248 & 0.246 \\
\hline & $\mathrm{R}_{\mathrm{es} / \mathrm{t}}^{\prime \prime}$ & 0.419 & 0.408 & 0.435 & 0.421 & 0.421 & 0.415 & 0.391 \\
\hline & $\mathrm{R}_{\mathrm{es} / \mathrm{t}}$ Area & A & $\mathrm{C}$ & $\mathrm{B}$ & $\mathrm{C}$ & A & A & A \\
\hline & Effluent was qualified & Yes & No & No & No & Yes & Yes & Yes \\
\hline
\end{tabular}

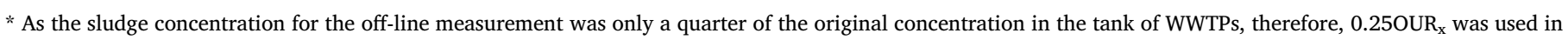
the respirogram space. 


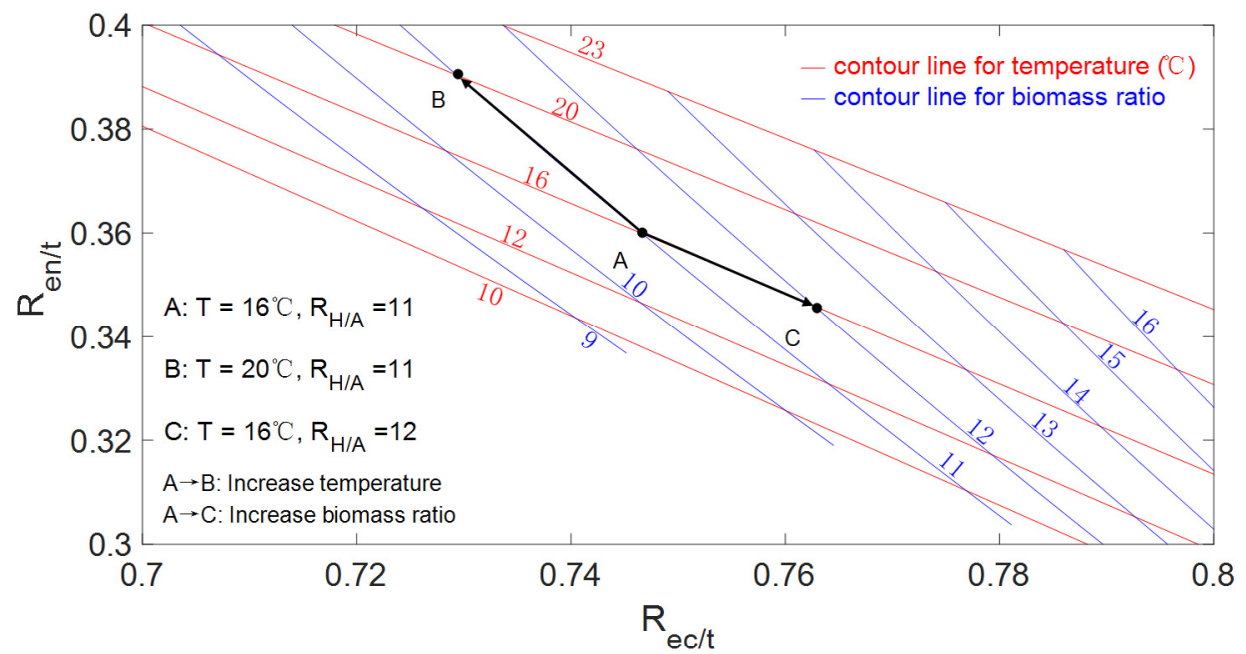

Fig. 3. Contour lines for temperature and biomass ratio as functions of $R_{e n / t}$ and $R_{e c / t}$.

and (8) $\mathrm{T}$ and $\mathrm{R}_{\mathrm{H} / \mathrm{A}}$ were calculated as $12.98^{\circ} \mathrm{C}$ and 12.34 , respectively. The critical value of $\mathrm{R}_{\text {es } / \mathrm{t}}$ and $\mathrm{R}^{\prime \prime}$ es/t of this plant under such operational conditions could be calculated from Eq. (6) (Fig. 4). The rectangular region in $\left(\mathrm{COD}, \mathrm{NH}_{4}{ }^{+}-\mathrm{N}\right)$ space could be divided into several areas according to the effluent discharge standards: Areas A and B2 were the safe areas for discharge, Areas B1 and B3 were uncertain areas in which either COD or $\mathrm{NH}_{4}{ }^{+}-\mathrm{N}$ exceeded the discharge limits, and Area $\mathrm{C}$ was a violent area, in which both $\mathrm{COD}$ and $\mathrm{NH}_{4}{ }^{+}-\mathrm{N}$ levels were higher than the discharge limits. However, $\mathrm{R}_{\mathrm{es} / \mathrm{t}}$ could only distinguish safe Area A and violent Area $\mathrm{C}$. Under the above operational conditions $\left(\mathrm{T}=12.98^{\circ} \mathrm{C}, \mathrm{R}_{\mathrm{H} / \mathrm{A}}=12.34\right)$, the values of $\mathrm{R}_{\mathrm{es} / \mathrm{t}}^{\prime}$ for the safe area boundary lines and $\mathrm{R}_{\mathrm{es} / \mathrm{t}}$ for the violent area boundary lines should be 0.24 and 0.42 , respectively. When $R_{\mathrm{es} / \mathrm{t}}$ was less than 0.24 (in Area A), the effluent was safe to discharge, and when $R_{\mathrm{es} / \mathrm{t}}$ was greater than 0.42 (in Area C), the effluent exceeded the discharge limits. However, when its value was between 0.24 and 0.42 (as in Area B), $R_{e s / t}$ alone could not determine whether it is safe to discharge. In this plant the measured $R_{\text {es/t }}$ was 0.16 (Table 2), less then $R_{\text {es/t }}^{\prime}$, so the effluent quality was in the safe discharge area A.

With Plant 5 as another example, the status point $\left(R_{e n / t}, R_{e c / t}\right)$ was $(0.34,0.78)$, as shown in Table 2 . Thus, the corresponding critical $R_{\text {es/t }}^{\prime}$ and $R^{\prime \prime}{ }_{\text {es } / t}$ was 0.23 and 0.42 , respectively. The measured $R_{e s / t}$ was $0.13 \pm 0.03$. As a result, the effluent quality was in the safe discharge area A. For Plant 4 , the respirogram status point was $(0.32,0.79)$, very close to that of Plant 5 . However, the measured $R_{\mathrm{es} / \mathrm{t}}$ was 0.44 , greater than the $\mathrm{R}^{\prime \prime}$ es/t of 0.42 , and thus located in violent area C. This result was evidenced by the measured effluent $\mathrm{COD}$ and $\mathrm{NH}_{4}{ }^{+}-\mathrm{N}$ values, which were over the limits of the Discharge Standards.

\subsection{Verification and merits of the respirogram-based approach}

Though our approach (Fig. 2) does not determine the exact constituent of the effluent, its strength lies in its simplicity and low cost. Namely, from the operator's perspective, it is sufficient to obtain information for fault detection from only a few data sources. The success of this approach was verified by the data from seven full-scale WWTPs (Table 2).

One-dimensional respirograms, generally denoted as OURs, have been widely used to describe the activity of activated sludge (Mannina et al., 2016b; Picioreanu et al., 2016). These respirograms are also frequently used for the estimation of biomass concentration and the influent compositions, e.g., biodegradable COD. All these works require calculation with complex mathematical models, e.g., ASM, for predicating the exact effluent quality (Alikhani et al., 2017). In contrast, the proposed multi-dimensional respirogram space alone could identify the effluent faults, which is much simpler than using other models. The coordinates of the respirogram space also provide useful information about activated sludge status. For instance, the $\mathrm{OUR}_{\mathrm{n}}$ could provide an appropriate description of the nitrification capacity. Additionally, parameters describing operational condition could also be calculated from the respirogram space coordinates and provide hints for solids retention time (SRT) control, e.g., for a smaller $R_{H / A}$, a longer SRT should be provided for the growth of nitrifiers.

In addition to deriving the informative data, the respirogram spacebased approach has another great merit of providing very robust signals

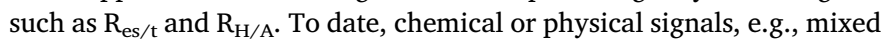
liquor suspended solids (MLSS), DO, oxidation-reduction potential, ammonia concentration and nitrate concentration, are frequently used for the control of activated sludge systems. However, signals describing biological status are hardly used in field applications, except for onedimensional OUR in some cases. Chemical or physical signals may vary chaotically over several minutes, and raise nuisance alarms $\left(\mathrm{O}^{\prime}\right.$ Donoghue et al., 2015), resulting in a high cost for device maintenance, such as frequent replacement of valves. In contrast, signals from

Table 3

Sensitivity analysis of the parameters on the estimation of $\mathrm{R}_{\mathrm{es} / \mathrm{t} \text {. }}$

\begin{tabular}{|c|c|c|c|c|c|c|c|c|c|c|}
\hline \multirow[t]{2}{*}{ WWTPs } & \multirow[t]{2}{*}{$\mathrm{R}_{\mathrm{en} / \mathrm{t}}$} & \multirow[t]{2}{*}{$\mathrm{R}_{\mathrm{ec} / \mathrm{t}}$} & \multirow[b]{2}{*}{$\mathrm{Y}_{\mathrm{H}}$} & \multirow[b]{2}{*}{$\mu_{H}$} & \multirow[b]{2}{*}{$\mathrm{K}_{\mathrm{s}}$} & \multirow[b]{2}{*}{$\mathrm{b}_{\mathrm{H}}$} & \multirow[b]{2}{*}{$\mu_{\mathrm{A}}$} & \multicolumn{3}{|l|}{$S_{i, j}$} \\
\hline & & & & & & & & $\mathrm{K}_{\mathrm{NH}}$ & $\mathrm{b}_{\mathrm{A}}$ & $\mathrm{Y}_{\mathrm{A}}$ \\
\hline 1 & 0.32 & 0.78 & $7.8 \times 10^{-3}$ & $2.8 \times 10^{-3}$ & $4.7 \times 10^{-3}$ & $5.5 \times 10^{-4}$ & $6.1 \times 10^{-4}$ & 0.1578 & $2.9 \times 10^{-3}$ & $7.1 \times 10^{-4}$ \\
\hline 2 & 0.30 & 0.81 & $5.9 \times 10^{-3}$ & $2.1 \times 10^{-3}$ & $3.5 \times 10^{-3}$ & $4.6 \times 10^{-4}$ & $7.1 \times 10^{-4}$ & 0.1590 & $2.5 \times 10^{-3}$ & $8.3 \times 10^{-4}$ \\
\hline 3 & 0.34 & 0.78 & $6.0 \times 10^{-3}$ & $2.1 \times 10^{-3}$ & $3.6 \times 10^{-3}$ & $5.4 \times 10^{-4}$ & $1.4 \times 10^{-4}$ & 0.1596 & $1.8 \times 10^{-3}$ & $1.6 \times 10^{-4}$ \\
\hline 4 & 0.32 & 0.79 & $6.5 \times 10^{-3}$ & $2.3 \times 10^{-3}$ & $3.9 \times 10^{-3}$ & $5.1 \times 10^{-4}$ & $4.5 \times 10^{-4}$ & 0.1589 & $2.3 \times 10^{-3}$ & $5.2 \times 10^{-4}$ \\
\hline 5 & 0.34 & 0.78 & $6.0 \times 10^{-3}$ & $2.1 \times 10^{-3}$ & $3.6 \times 10^{-3}$ & $5.4 \times 10^{-4}$ & $1.4 \times 10^{-4}$ & 0.1596 & $1.8 \times 10^{-3}$ & $1.6 \times 10^{-4}$ \\
\hline 6 & 0.31 & 0.80 & $6.2 \times 10^{-3}$ & $2.2 \times 10^{-3}$ & $3.7 \times 10^{-3}$ & $4.8 \times 10^{-4}$ & $5.8 \times 10^{-4}$ & 0.1589 & $2.4 \times 10^{-3}$ & $6.7 \times 10^{-4}$ \\
\hline 7 & 0.27 & 0.85 & $4.2 \times 10^{-3}$ & $1.5 \times 10^{-3}$ & $2.5 \times 10^{-3}$ & $3.4 \times 10^{-4}$ & $9.3 \times 10^{-4}$ & 0.1599 & $2.2 \times 10^{-3}$ & $1.1 \times 10^{-3}$ \\
\hline
\end{tabular}




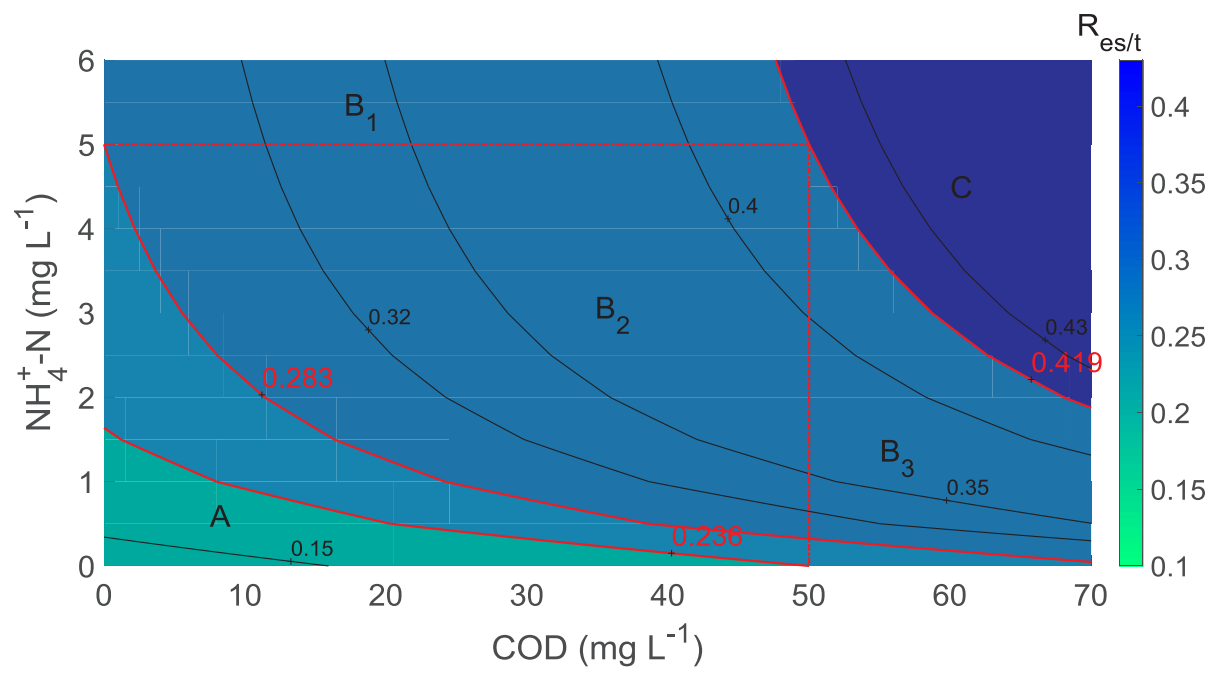

Fig. 4. Partition of the (COD, $\mathrm{NH}_{4}{ }^{+}-\mathrm{N}$ ) space (describing the effluent quality) into safe, violent, and uncertain areas according to the $\mathrm{R}_{\mathrm{es} / \mathrm{t}}$ value using the respirogram space information from Plant 1 (the minimum value 0.236 was selected as the boundary line for safe region).

biological status are more robust, because the variations of the coordinates of respirogram space are associated with the microbial growth and alter much more robustly than the chemical or physical signals. The sensitivity analysis of the parameters for critical $R_{\mathrm{es} / \mathrm{t}}$ calculation also confirms the robustness of the proposed method (Table 3 ). Therefore, the robust signals provided by the multi-dimensional respirogram support stable adjustments of operational conditions, which is favorable for activated sludge systems.

\subsection{Adaptability of the respirogram space method to the supervisory control and data acquisition (SCADA) system}

The measurement of OUR can be easily implemented online, and the multi-dimensional respirogram can also be automatically measured. Thus, the proposed method could be implemented in the SCADA (Supervisory Control and Data Acquisition) system for WWTPs. It could also be embedded into PLC, the most frequently used control unit. The relationship between the respirogram status $\left(R_{e c / t}, R_{e n / t}\right)$ and operational status $\left(T, R_{H / A}\right.$ ) should be calculated offline in advance using Eqs. (7) and (8), with the resulted data saved in a table format. The database could be easily used by the PLC language despite its limited capacity of the calculations, as the functions for searching values in a table and interpolation are generally available. Thus, automatic online control becomes possible. By further employing additional generally available online signals, such as MLSS, ammonia, COD and DO concentrations, automatic optimization could be realized. Despite the above-mentioned merits, our approach still has some limitations for practical applications, such as the missed prediction of total phosphorus (TP) and total nitrogen (TN). However, if additional coordinates describing the characteristics of phosphate-accumulating organisms (PAOs) or denitrifiers could be introduced into the respirogram space, these problems could be solved. This warrants further investigations.

\section{Conclusions}

In this work, several useful indexes have been derived from a multidimensional respirogram. Among them, $\mathrm{R}_{\mathrm{es} / \mathrm{t}}$ could be used as an alarm signal for the effluent quality control, and $\left(R_{\mathrm{ec} / \mathrm{t}}, \mathrm{R}_{\mathrm{en} / \mathrm{t}}\right)$ along with the effluent information could be used to infer operational status. Based on the theoretical framework, a simple and efficient toolkit for the effluent using only respirogram information was proposed, which was verified using the operating data from several full-scale WWTPs. The approach opens the door for managing WWTPs by respirometric analysis, which can be applied to any facilities mainly relying on activated sludge to treat the sewage.

\section{Acknowledgements}

This work was supported by the National Natural Science Foundation of China (51538011), the Bureau of Science and Technology of Xi'an City of China (2016063SF/SF09), the Department of Water Resources of Shaanxi Province of China (2017slkj-10), the West Light Foundation for the Visiting Fellow Program and the US National Science Foundation (DMS-1516951). Tian-yu Zhang would like to thank the support of Beijing Computational Science Research Center where part of his work was done.

\section{References}

Alikhani, J., Takacs, I., Al-Omari, A., Murthy, S., Massoudieh, A., 2017. Evaluation of the information content of long-term wastewater characteristics data in relation to activated sludge model parameters. Water Sci. Technol. 75, 1370-1389.

Bahar, S., Ciggin, A.S., 2016. A simple kinetic modeling approach for aerobic stabilization of real waste activated sludge. Chem. Eng. J. 303, 194-201.

Capodici, M., Fabio Corsino, S., Di Pippo, F., Di Trapani, D., Torregrossa, M., 2016. An innovative respirometric method to assess the autotrophic active fraction: application to an alternate oxic-anoxic MBR pilot plant. Chem. Eng. J. 300, 367-375.

Ciggin, A.S., Orhon, D., 2014. Effect of storage on the respirometric relationship between substrate utilization and microbial growth. Bioresour. Technol. 167, 331-335.

Dalmau, M., Atanasova, N., Gabarrón, S., Rodriguez-Roda, I., Comas, J., 2015. Comparison of a deterministic and a data driven model to describe MBR fouling. Chem. Eng. J. 260, 300-308.

Dulekgurgen, E., Doğruel, S., Karahan, Özlem, Orhon, D., 2006. Size distribution of wastewater cod fractions as an index for biodegradability. Water Res. 40, 273.

Dürrenmatt, D.J., Gujer, W., 2012. Data-driven modeling approaches to support wastewater treatment plant operation. Environ. Modell. Software 30, 47-56.

Foscoliano, C., Del Vigo, S., Mulas, M., Tronci, S., 2016. Predictive control of an activated sludge process for long term operation. Chem. Eng. J. 304, 1031-1044.

Friedrich, M., Takács, I., 2013. A new interpretation of endogenous respiration profiles for the evaluation of the endogenous decay rate of heterotrophic biomass in activated sludge. Water Res. 47, 5639-5646.

Friedrich, M., Takács, I., Tränckner, J., 2015. Physiological adaptation of growth kinetics in activated sludge. Water Res. 85, 22-30.

Hauduc, H., Gillot, S., Rieger, L., Ohtsuki, T., Shaw, A., Takács, I., Winkler, S., 2009. Activated sludge modelling in practice: an international survey. Water Sci. Technol. 60, 1943-1951.

Henze, M., Gujer, W., Mino, T., Van Loosdrecht, M.C.M., 2000. Activated Sludge Models ASM1, ASM2, ASM2d and ASM3. IWA Publishing, London.

Hreiz, R., Latifi, M.A., Roche, N., 2015. Optimal design and operation of activated sludge processes: state-of-the-art. Chem. Eng. J. 281, 900-920.

Jubany, I., Lafuente, J., Baeza, J.A., Carrera, J., 2009. Total and stable washout of nitrite oxidizing bacteria from a nitrifying continuous activated sludge system using automatic control based on oxygen uptake rate measurements. Water Res. 43, 2761-2772.

Karahan, O., Dogruel, S., Dulekgurgen, E., Orhon, D., 2008. COD fractionation of tannery wastewaters-particle size distribution, biodegradability and modeling. Water Res. 42, 1083-1092.

Kor-Bicakci, G., Ubay-Cokgor, E., Orhon, D., 2015. Acute impact of tetracycline on the 
utilization of acetate by activated sludge sustained under different growth conditions. Bioresour. Technol. 198, 157-164.

Li, Z.H., Zhu, Y.M., Zhang, J., Yang, C.J., Zhang, T.Y., Yu, H.Q., 2018a. Evaluation of robustness of activated sludge using calcium-induced enhancement of respiration. Bioresour. Technol. 253, 55-63.

Li, Z.H., Ma, Z.B., Yu, H.Q., 2018b. Respiration adaptation of activated sludge under dissolved oxygen and hypochlorite stressed conditions. Bioresour. Technol. 248, 171-178.

Mannina, G., Capodici, M., Cosenza, A., Di Trapani, D., 2016a. Carbon and nutrient biological removal in a University of Cape Town membrane bioreactor: analysis of pilot plant operated under two different C/N ratios. Chem. Eng. J. 296, 289-299.

Mannina, G., Capodici, M., Cosenza, A., Di Trapani, D., Viviani, G., 2016b. Sequential batch membrane bio-reactor for wastewater treatment: the effect of increased salinity. Bioresour. Technol. 209, 205-212.

Melcer, H., 2004. Methods for Wastewater Characterization in Activated Sludge Modeling. IWA Publishing.

Namour, P., Müller, M.C., 1998. Fractionation of organic matter from wastewater treatment plants before and after a 21-day biodegradability test: a physical-chemical method for measurement of the refractory part of effluents. Water Res. 32, 2224-2231.

O' Donoghue, N., Phillips, D.H., Nicell, C., 2015. Reducing SCADA system nuisance alarms in the water industry in Northern Ireland. Water Environ. Res. 87, 751-757.
Petersen, B., Gernaey, K., Henze, M., Vanrolleghem, P.A., 2002. Evaluation of an ASM1 model calibration procedure on a municipal industrial wastewater treatment plant. J. Hydroinf. 4, 15-38.

Picioreanu, C., Pérez, J., Van Loosdrecht, M.C.M., 2016. Impact of cell cluster size on apparent half-saturation coefficients for oxygen in nitrifying sludge and biofilms. Water Res. 106, 371-382.

Valverde-Pérez, B., Fuentes-Martínez, J.M., Flores-Alsina, X., Gernaey, K.V., Huusom, J.K., Plósz, B.G., 2016. Control structure design for resource recovery using the enhanced biological phosphorus removal and recovery (EBP2R) activated sludge process. Chem. Eng. J. 296, 447-457.

Van Loosdrecht, M.C.M., Henze, M., 1999. Maintenance, endogeneous respiration, lysis, decay and predation. Water Sci. Technol. 39, 107-117.

Van Loosdrecht, M.C.M., Lopez-Vazquez, C.M., Meijer, S.C.F., Hooijmans, C.M., Brdjanovic, D., 2015. Twenty-five years of ASM1: past, present and future of wastewater treatment modelling. J. Hydroinf. 17, 697-718.

Xu, Y.G., Deng, W.K., Song, B., Deng, X.Y., Luo, F., 2017. Pre-processing of imbalanced samples and the effective contribution in fault diagnosis in wastewater treatment plants. J. Hydroinf. 19, 251.

Zamouche-Zerdazi, R., Bencheikh Lehocine, M., Meniai, A.H., 2014. Influence of endogenous OUR determination on the $\mathrm{K}_{\mathrm{La}}$, exogenous OUR, total oxygen consumption and heterotrophic yield in a completely mixed batch reactor. Int. J. Chem. React. Eng. 12, 695-704. 